\title{
Penerapan Metode Permainan Dalam Meningkatkan Prestasi Belajar Matematika di Kelas IV SD
}

\author{
Murdani Susanto \\ Guru SDN Menyosok Praya Timur, Lombok Tengah, NTB \\ murdaniss@gmail.com
}

\begin{tabular}{l}
\hline \hline INFO ARTIKEL \\
\hline Riwayat Artikel: \\
Diterima: 09-02-2018 \\
Disetujui: 16-03-2018 \\
\\
\hline Kata Kunci: \\
Metode Permainan, \\
Perstasi Belajar, \\
Matematika \\
\end{tabular}

\begin{abstract}
ABSTRAK
Abstrak: Penelitian dalam dua siklus PTK mengenai penerapan metode permainan dalam upaya meningkatkan persetasi belajar Matematika siswa kelas IV SDN Menyosok Kecamatan Praya Timur Kabupaten Lombok Tengah. Diperoleh peningkatan hasil siklus I aktivitas siswa 56 dan siklus II sebesar 69 kategori sangat aktif. Sedangkan aktivitas guru siklus I sebesar 16 dan siklus II sebesar 18 dengan kategori sangat baik. Ketuntasan klasikal pada siklus I sebesar $60 \%$ sedangkan siklus II sebesar 88\% peningkatan sebesar 28\%. Dengan demikian Penerapan metode permainan dalam pembelajaran matematika meningkatkan prestasi belajar siswa kelas IV SDN Menyosok Kecamatan Praya Timur Lombok Tengah.
\end{abstract}

\begin{abstract}
Research in two PTK cycles on the application of game methods in an effort to improve students' learning achievement of Maths grade IV SDN Disosok East Praya District Central Lombok. Obtained increase of result of cycle I student activity 56 and cycle II equal to 69 category very active. While the activity of teachers cycle I of 16 and cycle II of 18 with very good category. Classical completeness in the first cycle of $60 \%$ while the second cycle of $88 \%$ increase by $28 \%$. Thus the application of game methods in learning mathematics improve student achievement grade IV SDN Diposok Kecamatan Praya Timur Lombok Tengah.
\end{abstract}

\section{A. LATAR BELAKANG}

Peningkatan pembelajaran Matematika di sekolah terus diupayakan untuk meningkatkan kualitas prestasi belajar siswa. Berbagai cara terus dilakukan, salah satunya dilakukan dengan mensinergikan komponen-komponen yang terlibat dalam pembelajaran. Komponen yang terlibat dalam pembelajaran tersebut adalah tujuan, bahan pelajaran (materi), kegiatan pembelajaran, metode, alat dan sumber serta evaluasi.

Pada pelajaran Matematika tentang Menyelesaikan masalah yang berkaitan dengan satuan waktu, panjang dan berat dengan tujuan pembelajaran menentukan cara menghitung berat suatu benda dalam kegiatan sehari-hari dengan indikator pencapaian dapat menggunakan kesetaraan satuan dalam perhitungan, melakukan hitungan berat dengan menggunakan alat hitung satuan berat tidak mencapai hasil yang maksimal, yang berakibat tidak dapat memanfaatkan konsep ini sebagai bekal selepas mereka dari bangku sekolah.
Pada umumnya metode yang digunakan guru dalam menyampaikan pelajaran adalah dengan metode ekspositori, yaitu dengan memaparkan informasi yang dianggap penting untuk siswa di awal pelajaran, memberikan definisi dan rumus, menjelaskan contoh soal dan cara pengerjaannya, memberikan soal-soal latihan untuk dikerjakan siswa dan kemudian memeriksa pekerjaan siswa di akhir pelajaran. Beberapa guru merasa cocok dengan metode tersebut, namun jika guru mengajar dengan metode yang sama pada setiap pertemuan maka tidak jarang akan ditemui siswa yang bosan untuk mempelajari materi ini, terjadi penurunan aktivitas belajar yang mengakibatkan menurunnya prestasi belajar Matematika siswa.

Salah satu upaya guru untuk meningkatkan kembali aktivitas dan prestasi belajar matematika siswa dalam mempelajari materi Menyelesaikan masalah yang berkaitan dengan satuan waktu, panjang dan berat adalah dengan melakukan perbaikan metode pembelajaran yang disesuaikan dengan komponen pembelajaran lainnya. Salah satu metode yang dapat guru gunakan adalah metode 
permainan. Sudjana (2000:138) mengungkapkan bahwa penyajian teknik permainan yang baik akan menarik perhatian peserta didik sehingga menimbulkan suasana yang mengasyikan tanpa menimbulkan kelelahan. Hal ini senada diungkapkan Djaramah (2002:139) salah satu upaya guru dalam memotivasi siswa adalah dengan menggunakan simulasi dan permainan. Hal ini dapat meningkatikan interksi, menyajikan gambaran yang jelas mengenai kehidupan sebenarnya dan melibatkan siswa secara langsung dalam pembelajaran.

Dalam materi Menyelesaikan masalah yang berkaitan dengan satuan waktu, panjang dan berat metode permainan yang dapat digunakan adalah permainan jual beli, yaitu metode permainan yang menetapkan agar pembelajaran bertitik tolak pada hal-hal konkrit bagi siswa. Hal ini dilakukan dengan memanipulasi benda-benda seperti uang mainan, timbangan, barang-barang dagangan, barang-barang yang menggunakan kemasan dan barang-barang yang tidak menggunakan kemasan ke dalam bentuk permainan.

\section{B. METODE PENELITIAN Setting Penelitian}

1. Tempat penelitian

Tempat penelitian ini yaitu di Kelas IV SD Negeri Menyosok Kecamatan Praya Timur Kecamatan Praya Timur Kabupaten Lombok Tengah tahun 2015/2016.

2. Waktu Penelitian

Penelitian ini dilakukan pada semester ganjil sejak bulan Agustus s.d. Oktober 2015 yang terbagi menjadi 2 siklus yaitu siklus I dilakukan pada hari Senin tanggal 10 Agustus 2015 dan siklus II dilakukan pada hari Senin tanggal 7 September 2016.

\section{Subyek dan observer}

\section{Subjek penelitian}

Subjek penelitian dalam kegiatan penelitian ini adalah kelas IV yang berjumlah 25 orang yang terdiri dari 15 orang siswa laki-laki dan 10 orang perempuan.

\section{Observer Penelitian}

Yang bertindak sebagai obsever pada penelitian ini adalah sdr. Mahnun, S.Pd. guru senior di SD Negeri Menyosok Kecamatan Praya Timur, sedangkan peneliti bertindak sebagai guru yang akan di amati pelaksanaan pembelajarannya.

\section{Variabel penelitian}

Berdasarkan judul penelitian yaitu penerapan metode permainan dalam meningkatkan prestasi belajar Matematika di kelas IV SD Negeri Menyosok Kecamatan Praya Timur tahun pelajaran 2015/2016, maka yang menjadi variabel dalam penelitian ini adalah :

1. Variabel bebas (independent variable) yaitu variabel yang dinilai atau besarnya tidak dipengaruhi oleh perubahan nilai variabel lainnya. Dalam penelitian ini yang menjadi variabel bebas adalah penerapan metode permainan.

2. Variabel terikat (dependent variable) yaitu variabel yang dinilai dan besarnya dipengaruhi oleh perubahan nilai variabel lainnya. Dalam penelitian ini yang menjadi variabel terikat adalah prestasi belajar Matematika.

\section{Prosedur Penelitian}

Prosedur yang digunakan dalam penelitian ini, mengembangkan sebagimana lazimnya dalam penelitian ini terdiri dari dua siklus dengan tahap-tahap kegiatan yang ditempuh pada tiap siklus meliputi empat kegiatan, yaitu : (1) Tahap perencanaan tindakan (paln), (2) Tahap pelaksanaan atau tindakan (action), (3) Tahap pengamatan (Observation), (4) Tahap perenungan (Reflective). (Arikunto, Suharsimi. 2002, $2002: 233$ )

Secara operasional siklus penelitian tindakan kelas dapat dijelaskan sebagai berikut :

\section{Tahap perencanaan (plan)}

Tahap perencanaan tindakan adalah langkah persiapan untuk : (a) Mengidentifikasi peningkatan prestasi belajar Matematika siswa kelas IV semester satu semester satu SD Negeri Menyosok Kecamatan Praya Timur Kabupaten Lombok Tengah, tahun pelajaran 2015/2016. (b) Menyusun rencana tindakan yang hendak dilakukan dalam penerapan metode permainan yaitu dengan menyusun rencana pembelajaran, menyusun aturan permainan, dan menyusun instrumen-instrumen yang akan digunakan. (c) Menyiapkan sumber, alat dan bahan yang hendak digunakan. Pada siklus I dibutuhkan 
buku paket Matematika kelas IV, LKS. Siklus II dibutuhkan buku paket Matematika IV, LKS, kartu peranan sebagai penjada toko dan konsumen, buku, pensil, tas dan penggaris yang kemudian akan digunakan sebagai barang dagangan, timbangan, gelas, beras, terigu dan gula pasir. (d) Mengidentifikasi masalah-masalah yang terdapat pada siklus sebelumnya serta menetapkan pemecahan masalahnya untuk siklus berikutnya.

\section{Tahap tindakan (action)}

'Tahap tindakan adalah kegiatan pelaksanaan penerapan metode kerja kelomok sesuai dengan rencana tindakan yang telah disusun sebelumnya. Pada siklus I tindakan yang dilakukan dimulai dengan membahas masalah sehari-hari dalam perdagangan untuk menanamkan konsep pada siswa tentang nilai keseluruhan, nilai per unit, dan nilai sebagian. Secara berkelompok siswa bekerja kelompok. Sebagai acuan dalam bermain, siswa diberikan format tabel yang harus diisi sesuai dengan peran yang dimainkannya. Membahas beberapa catatan yang dibuat oleh siswa selama permainan pengukuran dan menyimpulkan materi yang telah dipelajari.

Pada siklus II tindakan yang dilakukan dimulai dengan membahas masalah sehari-hari dalam perdagangan untuk memainkan konsep pada siswa tentang satuan berat, ton, kwintal, kg, dag, gram, cm, mg. Secara berkelompok siswa bermain jual beli dengan membagi peran, dua orang sebagai penjaga toko dan dua orang sebagai konsumen kemudian melakukan jual beli dengan menggunakan uang mainan sebagai alat pembayarannya. Sebagai acuan dalam bermain, siswa diberikan tabel format yang harus diisi sesuai dengan peran yang dimainkannya. Melakukan penimbangan beberapa barang dengan wadah/kemasannya dan penimbangan barang tanpa wadah/kemasannya dan mencatat dalam format tabel. Membahas beberapa catatan yang dibuat oleh siswa selama permainan jual beli dan menyimpulkan materi yang telah dipelajari.

Pada setiap akhir siklus dilakukan evaluasi dengan tes prestasi belajar Matematika siswa untuk mengetahui peningkatan prestasi belajar Matematika siswa kelas IV semester satu SD Negeri Menyosok Kecamatan Praya Timur
Kabupaten Lombok Tengah tahun pelajaran 2015/2016.

\section{Tahap pengamatan (observation)}

Tahap pengamatan adalah kegiatan langsung maupun tidak langsung untuk merekam semua peristiwa yang terjadi pada saat proses tindakan. Pengamatan ini digunakan untuk mengetahui peningkatan aktifitas belajar matematika siswa kelas IV semester satu SD Negeri Menyosok Kecamatan Praya Timur Kabupaten Lombok Tengah, tahun pelajaran 2015/2016.

4. Tahap Perenungan (reflection)

Tahap perenungan adalah kegiatan mengkaji hasil observasi dan merenungkan kembali proses-proses tindakan dengan berbagai permasalahannya. Dalam tahap perenungan ini diolah lembar observasi, jurnal siswa dan tes prestasi belajar Matematika siswa yang didapat dari tahap tindakan kemudian menganalisanya untuk melihat peningkatan aktivitas dan prestasi belajar Matematika. Kegiatan perenungan ini dilakukan untuk menentukan, merekomendasi dan mendapatkan masukan bagi perbaikan rencana selanjutnya.

\section{Metode pengumpulan data}

Untuk keperluan pengumpulan data tentang proses dan hasil yang dicapai dipergunakan :

1. Nilai Ulangan Harian Matematika

Nilai ulangan harian matematika siswa didapat dari nilai ulangan pada materi satuan waktu, panjang dan berat tentang menentukan hubungan antara satuan waktu yaitu materi sebelum dilakukannya penelitian ini.

Dari ulangan harian yang dilakukan oleh siswa pada materi pengukuran berat diperoleh nilai rata-rata sebesar 50,37 dan persentasenya siswa yang mencapai standar ketuntasan belajar sebesar 60\%.

\section{Tes Prestasi Belajar}

Prestasi belajar merupakan perubahan perilaku dalam individu yang dimanfaatkan kedalam pola pengetahuan sebagai hasil belajar yang disadari dan dicapai setelah melakukan pembelajaran pada materi Menyelesaikan masalah yang berkaitan dengan satuan waktu, panjang dan berat dengan metode permainan. Tes prestasi belajar yang digunakan dalam bentuk uraian karena dengan tes uraian akan terlihat kemampuan dan proses berpikir siswa 
yang diberikan setiap akhir siklus, untuk siklus satu memuat dua puluh butir soal, untuk siklus II memuat 5 butir soal.

3. Lembar Observasi

Lembar observasi berisi daftar jenis aktivitas belajar siswa yang mungkin timbul dan akan diamati selama pembelajaran Matematika dengan permainan jual beli berlangsung. Hasil dari lembar observasi ini disajikan data aktifitas belajar Matematika siswa dan bahan perenungan untuk perbaikan tiap siklus.

4. Jurnal Siswa

Jurnal siswa diberikan di setiap akhir siklus dengan maksud untuk merekam semua peristiwa yang terjadi pada saat proses tindakan, kendala tindakan, langkah-langkah tindakan, permasalahan lain yang mungkin timbul selama pelaksanaan tindakan serta gagasan untuk siklus berikutnya.

\section{Instrumen pengumpulan data}

Suharsimi (2001:136) Instrumen penelitian adalah alat atau fasilitas yang digunakan oleh peneliti dalam mengumpulkan data agar pekerjaannya lebih mudah dan hasilnya lebih baik, dalam arti lebih cermat, lengkap, sistematis sehingga lebih mudah diolah. Instrumen perlakuan yang peneliti gunakan dalam penelitian ini adalah Rencana Pelaksanaan Pembelajaran (RPP). Adapun instrument pelengkap yang peneliti gunakan adalah sebagai berikut

1. Lembar Observasi

a. Lembar Observasi Aktivitas Guru Lembar observasi merupakan alat pengamatan yang digunakan untuk melihat aktivitas guru dan siswa serta bahan refleksi selama pembelajaran berlangsung. (lemabr observasi terlampir)

b. Lembar Observasi Aktivitas Siswa Lembar aktivitas siswa ini digunakan untuk mengetahui dan memantau respons atau reaksi siswa dalam pembelajaran. Lembar aktivitas siswa tersebut digunakan sebagai bahan refleksi terhadap pembelajaran.

\section{Teknik Analisis Data}

1. Data Hasil Observasi a. Observasi Aktivitas Guru

b. Menentukan skor aktivitas maksimal yang ideal

c. Menentukan mean ideal (MI) dan standar deviasi ideal (SDI)

Analisis data aktivitas guru menggunakan MI (Mean Ideal) dan SDI (standar devasi) dengan rumus:

MI $=\frac{1}{2} \times($ skor maksimal + skor minimal)

SDI $=\frac{1}{6} \times$ MI (skor max - skor min )

Keterangan :

Mi : Mean Ideal

SDi : Standar Deviasi Ideal

d. Observasi Aktivitas Siswa

1. Menentukan skor

2. Menentukan skor aktivitas maksimal yang ideal

3. Menentukan Mean Ideal (MI) dan Standar Deviasi Ideal (SDI)

Analisis data aktivitas belajar siswa menggunakan MI (mean ideal) dan SDI (standar deviasi) dengan rumus:

$$
\begin{aligned}
& \text { MI }=\frac{1}{2} \times \text { (skor maksimal + skor minimal) } \\
& \text { SDI } \quad=\frac{1}{6} \times \text { MI } \\
& \text { Keterangan : } \\
& \text { Mi : Mean Ideal } \\
& \text { SDi : Standar Deviasi Ideal }
\end{aligned}
$$

4. Menentukan kriteria aktivitas belajar Menghitung Data Prestasi Belajar Siswa

Untuk mengetahui data hasil tes belajar siswa akan dianalisis dengan rumus :

$$
\begin{aligned}
& \text { KK }=\frac{P}{N} \times 100 \% \\
& \text { Keterangan }: \\
& \text { KK= } \\
& \mathrm{P} \quad=\text { Jumlah siswa yang memperoleh } \\
& \quad \text { nilai } \geq \text { KKM } \\
& \mathrm{N}=\text { Jumlah Siswa yang mengikuti tes }
\end{aligned}
$$

Pedoman Penentuan Indeks Prestasi Kelompok
a) $90-100$
$=$ Sangat tinggi
b) $75-89$
$=$ tinggi
c) $55-74$
$=$ normal
d) $31-54$
$=$ rendah
e) $0-30$
= sangat rendah

(Nurkencana,1983:89) 


\section{Indikator Keberhasilan}

Penelitian ini dikatakan berhasil jika terjadi peningkatan prestasi belajar siswa. Prestasi belajar siswa dikatakan meningkat apabila $\mathrm{KK} \geq$ 85\% . Hasil belajar dikatakan meningkat apabila hasil belajar minimal berkatagori sedang.

\section{HASIL DAN PEMBAHASAN}

\section{Hasil penelitian}

\section{Siklus I}

Berdasarkan permasalahan melalui data pada observasi awal, kemudian dibuat perencanaan tindakan untuk siklus I. Adapun tahap perencanaan tindakan untuk siklus I adalah:

a. Menyusun rencana pembelajaran

b. Membuat soal tes prestasi belajar matematika siswa yang memuat materi tentang pengukuran berat.

c. Membuat lembar observasi dan jurnal siswa.

d. Mempersiapkan sumber, alat dan bahan berupa buku paket matematika kelas IV, LKS.

e. Mempersiapkan foto untuk dokumentasi.

Pertemuan siklus pertama dilaksanakan pada hari Senin tanggal 10 Agustus 2015. Guru bersama siswa menyiapkan tempat, sumber. Bahan dan alat yang akan digunakan. Siswa dibagi ke dalam 6 kelompok satu kelompok terdiri dengan 4-5 orang siswa. Secara berkelompok siswa bermain pengukuran suatu benda dengan membagi peran, dua orang sebagai pengukur dan dua orang sebagai pencatat pengukuran..

\section{a. Observasi Aktivitas Guru}

Data aktivitas guru dalam melaksanakan kegiatan pembelajaran diperoleh dengan menggunakan lembar observasi aktivitas guru. Adapun hasil observasi aktivitas guru siklus I.

\section{b. Observasi Aktivitas Siswa}

Berdasarkan analisis hasil observasi aktivitas siswa dari tiap indikator yang ditetapkan terdapat dua indikator yang belum maksimal dilakukan oleh sebagian besar siswa yaitu interaksi siswa dengan guru dan partisipasi siswa dalam menyimpulkan hasil belajar

\section{c. Hasil Evaluasi Menyelesaikan masalah yang berkaitan dengan satuan panjang Siklus I}

Evaluasi dilaksanakan untuk mengukur sejauh mana kemampuan siswa terhadap materi yang diajarkan dengan menggunakan Permainan matematika. Evaluasi pada siklus I dideskripsikan sebagai berikut.

TABEL 1.

REKAPITULASI HASIL EVALUASI SIKLUS I

\begin{tabular}{lc}
\hline Jumlah siswa & 25 \\
\hline Skor Rata-rata Siklus I & 73.28 \\
\hline Skor tertinggi Siklus I & 83 \\
\hline Skor terendah Siklus I & 62 \\
\hline Jlh skor tertinggi + rendah (M) & 145 \\
\hline Jlh skor tertinggi - rendah (R) & 21 \\
\hline $\begin{array}{l}\text { Kreteria ketuntasan Minimal } \\
\text { (KKM) Siklus I }\end{array}$ & 70 \\
\hline -Jumlah siswa Tuntas Siklus I & 15 \\
\hline -Jumlah Siswa Tidak tuntas Siklus I & 10 \\
\hline Ketuntasan Klasikal & $60 \%$ \\
\hline
\end{tabular}

Berdasarkan hasil tabel evaluasi Penggunaan metode permainan jual beli Mata Pelajaran Matematika siswa kelas IV SD Negeri Menyosok Kecamatan Praya Timur tentang Menyelesaikan masalah yang berkaitan dengan satuan waktu, panjang dan berat di atas, skor tertinggi yang didapat siswa adalah 83 dan skor terendah 62. Sehingga nilai rata-rata Mata Pelajaran Matematika siswa kelas IV SD Negeri Menyosok Kecamatan Praya Timur siswa pada siklus I sebesar 73,28. Persentase ketuntasan klasikal yang diperoleh yaitu 60,00\%. Dari nilai rata-rata tersebut dapat dikatakan bahwa, kemampuan memahami Menyelesaikan masalah yang berkaitan dengan satuan waktu, panjang dan berat siswa kelas IV SD Negeri Menyosok Kecamatan Praya Timur masih banyak yang belum mencapai standar ketuntasan maksimal 70. Selain itu, presentasi ketuntasan belajar (klasikal) siswa juga belum mencapai standar yang telah ditetapkan oleh penulis yaitu $85 \%$. Dengan demikian perlu adanya perbaikan di siklus berikutnya.

Selanjutnya hasil evaluasi siklus I akan digambarkan ketuntasannya dalam diagram berikut.

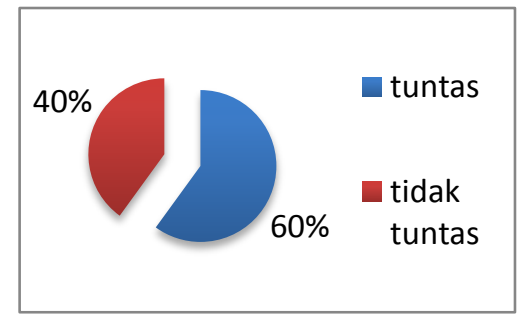

Gambar 1. Hasil Evaluasi Siklus I 
Berdasarkan hasil jurnal siswa pada siklus I, diketahui bahwa dari 25 siswa, sebanyak 9 siswa atau $36 \%$ menyatakan sangat senang dan tertarik dengan pembelajaran permainan matematika, sebanyak 6 siswa atau 24\% menyatakan senang dan 10 orang siswa atau 40\% menyatakan kurang senang seperti dalam diagram berikut.

\section{d. Mencari Kemampuan Individual}

Berdasarkan kriteria penelitian yang digunakan, maka selanjutnya dapat digunakan Standar Maksimal Ideal (SMI), Mean (M) dan Standar Deviasi Ideal (SDI), ketentuan klasikal. Adapun rumus untuk menentukan Standar Maksimal Ideal (SMI), Mean (M) dan Standar Deviasi Ideal (SDI). Dari rumus tersebut maka dapat ditentukan komponen-komponen tersebut sebagai berikut.

1. Menentukan SMI $=100$

2. Menentukan MI

$$
=\frac{1}{2} \times(\mathrm{ST}+\mathrm{SR})=\frac{1}{2} \times(83+62)=145
$$

3. Menentukan nilai $\mathrm{R}=\mathrm{ST}-\mathrm{SR}=83$ $-62=21$

4. Menentukan SDI $=\frac{1}{6} \times \mathrm{R}=\frac{1}{6} \times 21=3,50$

Berpedoman pada pola di atas maka dapat diterjemahkan bahwa setiap siswa yang memperoleh skor 76,00 - 83 ke atas dinyatakan memiliki kemampaun tinggi, siswa yang memperoleh skor 69,00 - 75 dinyatakan memiliki kemampuan sedang, dan siswa yang memperoleh skor $<75$ ke bawah dinyatakan memiliki kemampuan rendah .

Berdasarkan kriteria dan data yang diperoleh sebagaimana yang tertera di atas, pada semester satu tahun pelajaran 2015/2016 siklus I, dapat diketahui siswa yang memiliki kategori kemampuan tinggi, sedang dan rendah dapat diterjemahkan sebagai berikut.

1. Kemampuan siswa kategori tinggi : 10 orang $=40 \%$

2. Kemampuan siswa kategori sedang : 7 orang $=28 \%$

3. Kemampuan siswa kategori rendah : 8 orang $=32 \%$

\section{e. Mencari Kemampuan Kelompok}

Untuk mencari nilai kemampuan kelompok mempelajari Menyelesaikan masalah yang berkaitan dengan satuan waktu, panjang dan berat siswa kelas IV semester satu SD Negeri Menyosok Kecamatan Praya Timur, dicari dengan menggunakan rumus.

$$
\begin{gathered}
M=\frac{\sum x}{N} \\
\text { Di mana }
\end{gathered}
$$

$$
\begin{array}{ll}
\mathrm{M} & =\text { Kemampuan kelompok } \\
\sum \mathrm{fx} & =\text { Skor keseluruhan } \\
\mathrm{N} & =\text { Jumlah siswa (responden) }
\end{array}
$$

Berdasarkan data di atas, maka dapat ditentukan komponen-komponen yang diperlukan dalam menemukan kemampuan kelompok yaitu: jumlah keseluruhan nilai kemampuan belajar sebelum menggunakan pembelajaran kooperatif model number heads together sebagai berikut.

$\begin{array}{lll}\sum \mathrm{fx} & =1832 \\ \mathrm{~N} & =25\end{array}$

Selanjutnya memasukkan data kedalam rumus, yaitu

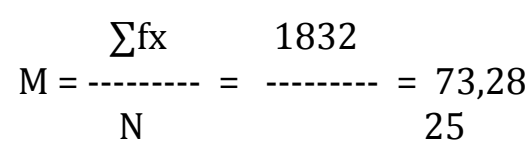

\section{e. Mencari Indeks Prestasi Kelompok (IPK)}

$$
\begin{aligned}
& \text { IPK }=\underset{\text { SMI }}{\text { - }} \\
& \begin{aligned}
\text { IPK } & =\frac{73,28}{-} \\
-100 & \times 100 \\
& =73,28
\end{aligned}
\end{aligned}
$$

Pedoman Penentuan Indeks Prestasi Kelompok

$$
\begin{array}{cc}
\text { IPK } \geq 90 & =\text { Sangat tinggi } \\
75 \leq \text { IPK }<89 & =\text { Tinggi } \\
55 \leq \text { IPK }<75 & =\text { Normal } \\
35 \leq \text { IPK }<55 & =\text { Sedang } \\
\text { IPK }<30 & =\text { Rendah }
\end{array}
$$

Dari hasil analisis data siklus I di atas diketahui bahwa Indek Prestasi Kelompok (IPK) = 73,28 ini menunjukkan bahwa kemampuan 
pembelajaran Penerapan metode permainan dalam pembelajaran matematika dapat meningkatkan prestasi belajar Kompetensi dasar Menyelesaikan masalah yang berkaitan dengan satuan waktu, panjang dan berat siswa kelas IV semester satu SD Negeri Menyosok Kecamatan Praya Timur Kabupaten Lombok Tengah pada semester satu tahun pelajaran 2015/2016, memiliki kemampuan normal.

\section{Siklus II}

Siklus II dilaksanakan pada hari 7 September 2015. Siklus ini pelaksanaannya sama dengan siklus I yakni dilakukan satu kali pertemuan $(2 \mathrm{x}$ 35 menit). Pertemuan ini adalah pelaksanaan permainan jual beli. Walaupun dilaksanakan di dalam ruangan siswa tetap semangat dalam melaksanakan permainan. Sebelum permainan dimulai terlebih dahulu guru memberikan informasi mengenai tujuan dari permainan kemudian bersama siswa menyiapkan tempat, sumber, bahan dan alat yang akan digunakan. Siswa dibagi ke dalam beberapa kelompok satu kelompok terdiri dari 4-5 orang siswa. Secara berkelompok siswa bermain jual beli dengan membagi peran, satu orang sebagai penjual, satu orang sebagai pelayan toko dan dua orang sebagai konsumen kemudian melakukan permainan dengan uang mainan sebagai alat pembayarannya. Sebagai acuan dalam bermain, siswa diberikan format table dalam aturan permainan yang harus diisi sesuai dengan peran yang dimainkannya. Siswa tampak menghayati peran yang dimainkannya, di sela permainan terdengar siswa mengungkapkan gagasannya kepada guru "Nanti kalau saya besar saya mau jadi Pedagang, bu?".

Setelah permainan usai, siswa bersama kelompoknya mendiskusikan catatan yang diperoleh selama permainan. Guru dengan teliti memeriksa hasil dari permainan, memeriksa tabel dan menyesuaikan dengan peran yang dimainkan. Kemudian guru membahas beberapa catatan yang dibuat oleh siswa tersebut dan bersama-sama menyimpulkan materi yang telah dipelajari.

Berikut adalah pemaparan hasil observasi kegiatan guru dan kegiatan siswa dengan penerapan metode permainan jual beli Mata Pelajaran Matematika siswa kelas IV SD Negeri Menyosok Kecamatan Praya Timur Kabupaten
Lombok Tengah tahun pelajaran 2015/2016 pada siklus II.

a. Observasi Aktivitas Guru

Berdasarkan kriteria aktivitas guru yang tercantum pada bab III terletak pada interval $16 \geq$ $A_{g} \geq 20$. Pada siklus II, guru melakukan pembelajaran dengan baik dan menarik perhatian siswa serta menyenangkan dalam menjelaskan materi kelanjutan operasi hitung bilangan bulat campuran dengan Penggunaan metode permainan jual beli Mata Pelajaran Matematika siswa kelas IV SD Negeri Menyosok Kecamatan Praya Timur Kabupaten Lombok Tengah tahun pelajaran 2015/2016 selain itu interaksi dengan siswa sudah aktif. Meskipun tipe yang digunakan tergolong baru, guru menyampaikan materi tentang Penggunaan metode permainan jual beli dengan jelas.

b. Observasi Aktivitas Siswa

Berdasarkan kriteria aktivitas siswa yang tercantum pada bab III berada pada interval $61>$ $A_{s} \geq 60$ (data lengkap terlampir). Pada pelaksanaan siklus II, aktivitas siswa sudah mengalami peningkatan. Siswa melakukan aktivitas pembelajaran dengan sangat aktif.

TABEL 2

REKAPITULASI HASIL EVALUASI SIKLUS II

\begin{tabular}{lc}
\hline Jumlah Siswa & 25 \\
\hline Skor Rata-rata & 77,56 \\
\hline Skor tertinggi & 84 \\
\hline Skor terendah & 63 \\
\hline Jlh skor tertinggi + rendah (M) & 147 \\
\hline Jlh skor tertinggi - rendah (R) & 21 \\
\hline$\quad$ Kreteria Ketuntasan Minimal \\
(KKM) Siklus II & 70 \\
\hline$\quad$-Jumlah siswa Tuntas Siklus II & 22 \\
\hline$\quad$-Jumlah Siswa Tidak tuntas Siklus & 3 \\
II $\quad$-Ketuntasan Klasikal Siklus II & $88 \%$ \\
\hline
\end{tabular}

Berdasarkan hasil tabel evaluasi Belajar Menyelesaikan masalah yang berkaitan dengan satuan waktu, panjang dan berat dengan metode permainan jual beli Mata Pelajaran Matematika siswa kelas IV SD Negeri Menyosok Kecamatan Praya Timur Kabupaten Lombok Tengah tahun pelajaran 2015/2016 di atas, dapat dikatakan bahwa siswa yang mencapai standar kemampuan bebrhitung tinggi berjumlah 16 orang siswa atau 64\%. Siswa yang memperoleh kemampuan berhitung sedang sebanyak 6 orang atau $24 \%$ dan siswa yang memiliki kemampuan 
rendah adalah 3 orang atau 12\%. Sedangkan persentase ketuntasan klasikal yang diperoleh yaitu $88,00 \%$. Nilai tertinggi dalam siklus II adalah 84 dan nilai terendah adalah 63 .

Berdasarkan masalah yang berkaitan dengan satuan waktu, panjang dan berat tinggi dalam siklus II termasuk katagori tinggi sebanyak 16 orang atau 64\%. Siswa yang memiliki kemampuan sedang dalam memahami Menyelesaikan masalah yang berkaitan dengan satuan waktu, panjang dan berat pada siklus II termasuk katagori sedang sebanyak 6 orang atau $24 \%$. Siswa yang memiliki kemampuan berkatagori rendah sebanyak 3 orang atau $12 \%$. Nilai tertinggi pada siklus II ini sebesar 84 dan nilai terendah sebesar 63 dengan nilai rata-rata 77,56 .

Berdasarkan hasil jurnal siswa pada siklus II, diketahui bahwa dari 25 siswa, sebanyak 18 siswa atau $72,00 \%$ menyatakan sangat senang dan tertarik dengan pembelajaran metode permainan jual beli Sebanyak 5 siswa atau $20,00 \%$ menyatakan senang. Sebanyak 2 siswa atau $8 \%$ menyatakan kurang senang..

Perubahan-perubahan yang dilakukan pada siklus II ini ternyata terbukti bisa merubah perolehan hasil belajar siswa, dengan ketercapaian persentase ketuntasan klasikal dari siklus I sebesar $60 \%$ meningkat menjadi $88 \%$ pada siklus II. Pencapaian ini sudah memenuhi target dari guru (peneliti) yang menetapkan standar ketuntasan yaitu 85\%. Sehingga penelitian ini berhenti di siklus II dan tidak di lanjutkan ke siklus selanjutnya dimana mengalami peningkatan sebesar $28 \%$.

\section{Pembahasan}

Berdasarkan hasil analisis data pelaksanaan tindakan pada siklus I menunjukkan bahwa persentase ketuntasan klasikal kemampuan memahami Menyelesaikan masalah yang berkaitan dengan satuan waktu, panjang dan berat adalah $60 \%$. Hal ini menunjukkan bahwa hasil belajar siswa belum tuntas. Jika dilihat dari hasil evaluasi tes kemampuan memahami Menyelesaikan masalah yang berkaitan dengan satuan waktu, panjang dan beratn, aktivitas siswa dan guru masih belum mencapai target yang diinginkan.
Sedangkan berdasarkan hasil analisis siklus II diperoleh ketuntasan belajar siswa yakni 88\%. Keberhasilan ini juga diperkuat karena adanya peningkatan ketuntasan yang terjadi dari siklus I ke siklus II sebesar 28\%. Berdasarkan hasil pembelajaran yang diperoleh, dapat dibuktikan bahwa metode permainan jual beli dapat meningkatkan kemampuan hasil belajar siswa. Hal-hal yang menyebabkan peningkatan hasil belajar siswa dari siklus I ke siklus II.

TABEL 3

PERBANDINGAN AKTIVITAS BELAJAR SISWA DAN GURU PADA SIKLUS I SIKLUS II

\begin{tabular}{llcc}
\hline No & \multicolumn{1}{c}{ Aspek } & $\begin{array}{c}\text { Hasil } \\
\text { siklus I }\end{array}$ & $\begin{array}{c}\text { Hasil } \\
\text { siklus II }\end{array}$ \\
\hline 1. & Jumlah siswa & 25 orang & 25 orang \\
\hline 2. & Rata-rata Nilai & 73,28 & 77,56 \\
\hline 3. & Nilai terendah & 62 & 63 \\
\hline 4. & Nilai tertinggi & 83 & 84 \\
\hline 5 & Aktivitas Siswa & 56 & 69 \\
\hline 6 & Aktivitas Guru & 16 & 18 \\
\hline 7. & Jumlah siswa tidak & 10 & 3 \\
\hline 8 & tuntas & & \\
\hline 9. & Jumlah siswa tuntas & 15 & 22 \\
\hline
\end{tabular}

Dari data tersebut dapat dilihat bahwa aktivitas belajar siswa meningkat maka hasil belajar siswa pun meningkat. Melalui penerapan metode permainan jual beli secara optimal, hasil belajar mengalami peningkatan pada siklus II.

Dengan demikian, penggunaan metode permainan jual beli dapat meningkatkan hasil belajar siswa kelas IV SD Negeri Menyosok Kecamatan Praya Timur tahun pelajaran 2015/2016.

Adapun perbedaan hasil siklus I dan siklus II meningkat dalam penerapan metode permainan jual beli di Kelas IV SD Negeri Menyosok Kecamatan Praya Timur Kabupaten Lombok Tengah disebabkan oleh beberapa faktor sebagai berikut :

1. Penerapan metode dan tipe pembelajaran pada siklus II lebih maksimal jika dibandingkan pada siklus I.

2. Konsentrasi belajar pada siklus II terlihat lebih menyenangkan darMatematikada pada siklus I.

3. Antusiasme siswa pada siklus II lebih antusias jika dibandingka siklus I 


\section{SIMPULAN DAN SARAN}

\section{Simpulan}

Berdasarkan hasil penelitian dan pembahasan hasil analisis data dapat ditarik kesimpulan bahwa metode permainan jual beli dapat meningkatkan hasil belajar siswa kelas VI SD Negeri Menyosok Desa Bilelando Kecamatan Praya Timur Tahun Pelajaran 2015/2016. Peningkatan ini dapat dilihat dari ketuntasan klasikal yang diperoleh pada siklus I yaitu sebesar $60 \%$ dan siklus II meningkat menjadi $88 \%$ dengan peningkatan sebesar $28 \%$. Peningkatan ini dapat dilihat dari hasil observasi aktivitas guru sebesar 16 dengan kategori baik pada siklus I dan meningkat menjadi 18 dengan kategori sangat baik pada siklus II. Sedangkan aktivitas siswa pada siklus I sebesar 56 dengan katagori aktif, meningkat menjadi 69 dengan kategori sangat aktif pada siklus II.

\section{Saran}

Adapun saran-saran yang dapat disampaikan sehubungan dengan hasil penelitian ini sebagai berikut:

a. Bagi siswa. Dalam proses belajar mengajar sebaiknya tetap melakukan interaksi atau kerjasama baik pada saat menyelesaikan permasalahan ataupun pada saat mempelajari suatu materi pelajaran, serta harus tetap mempersiapkan diri pada saat akan memulai maupun pada saat mengikuti proses belajar mengajar dengan sungguhsungguh.

b. Bagi guru. Dalam proses belajar mengajar Matematika tentang Menyelesaikan masalah yang berkaitan dengan satuan waktu, panjang dan berat sebaiknya menggunakan permainan jual beli agar senantiasa dapat meningkatkan aktifitas dan hasil belajar siswa .

c. Bagi sekolah. Penelitian ini dapat dijadikan acuan dalam pemecahan masalah yang berkaitan dengan upaya meningkatkan kemampuan, aktifitas dan prestasi belajar siswa. Sekolah dapat merekomendasi penggunaan metode inovatif seperti permainan jual beli pada mata pelajaran Matematika.

d. Bagi peneliti berikutnya. Peneliti yang ingin mengkaji tentang hal yang sama diharapkan untuk mengkaji secara lebih mendalam mengenai metode ini, serta kekurangankekurangan pada penelitian ini diharapkan dapat diminimalisasi agar mendapatkan hasil yang lebih baik.

\section{UCAPAN TERIMA KASIH}

Dengan penuh rasa hormat, saya ucapkan teimakasih kepada:
1. Kepala Dinas Pendidikan yang telah memfasilitasi, mengizinkan penulis untk mengadakan penelitian hingga dapat terlaksana dengan baik.

2. Bapak Kepala sekolah yang selalu memberi dukungan sejak awal hingga terlaksananya penelitian ini dengan baik.

3. Guru-guru yang telah memberi dukungan baik secara moral maupun tindakan langsung dalam pelaksanaan penelitian ini.

\section{REFERENSI}

[1]. Arikunto, Suharsimi. (2002). Prosedur Penelitian, Rineka Cipta Jakarta

[2]. Bahri, Syaiful Djamarah. (2002). Strategi Belajar Mengajar. Rineka Cipta Jakarta

[3]. Nurkencana,W,.dan Sunartana. (1998). Evaluasi Hasil Belajar. Surabaya : Usaha Nasional

[4]. Sanjaya, Wina. (2010). Strategi Pembelajaran Berorientasi Standar Proses Pendidikan. Prenada Media Grup. Jakarta.

[5]. Slameto. (2003). Belajar dan Faktor-faktor yang Mempengarufinya. Jakarta: Rineka Cipta.

[6]. Sudjana, Nana. (1995). Psikologi Pendidikan. Bandung: Cipta Karya 